\title{
PORTFOLIO INVESTMENT ANALYSIS ON THE BASIS OF THE BLACK-LITTERMAN MODEL
}

\author{
Alexey G. Isavnin ${ }^{1}$ \\ Damir R. Galiev \\ Anton N. Karamyshev ${ }^{3}$ \\ Ilnur I. Makhmutov ${ }^{4}$
}

\begin{abstract}
The works of Markowitz, Tobin, Sharp in the field of portfolio investment theory are awarded the Nobel Prize in economics. The popularity of these models is explained by their mathematical simplicity and logical harmony. But these models require accurate knowledge of the statistical features of assets and use assumptions about ideal market behavior. A large number of questions immediately arise on how to evaluate the input parameters of these models in the practical use of these models. In the Black-Litterman model, an attempt is made to combine the theory of equilibrium in the capital market with the subjective opinions of analysts regarding the expected return on assets and their relationship to each other. The Black-Litterman model
\end{abstract} makes it possible to combine the theory of market equilibrium and the subjective opinions of investors about asset behavior in the market. The result is a diversified portfolio with a subjective opinion on the situation. This model is a new word in portfolio theory, which is relatively complex and focused on professionals. Due to the Bayesian approach, it is formed a new, more realistic mixed estimate of expected returns, taking into account the opinions of expert analysts. In Western literature, the Black-Litterman model is recognized as an important and powerful tool in the process of portfolio investment management. In particular, the work discusses in detail the issues of collecting, analyzing and preparing expert opinions. The ability to take into

\footnotetext{
${ }^{1}$ Kazan Federal University. e-mail: antonkar2005@ yandex.ru. Tel.: +7-960-067-65-50

${ }^{2}$ Kazan Federal University. e-mail: antonkar2005@yandex.ru. Tel.: +7-960-067-65-50

${ }^{3}$ Kazan Federal University. e-mail: antonkar2005@yandex.ru. Tel.: +7-960-067-65-50

${ }^{4}$ Kazan Federal University. e-mail: antonkar2005@yandex.ru. Tel.: +7-960-067-65-50
} 
account the expert assessments is the main advantage of this model over all others.

Keywords: Black-Litterman model, portfolio investment, analysis, uncertainty, risk, profitability.

\section{Introduction}

The main goal of this work is to disclose the principles of optimal and meaningful management of a securities portfolio using one of the latest achievements in the field of portfolio theory - the Black-Litterman model, modernization of existing solutions and software development to solve such problems.

\section{Text Of Article}

Until recently, modern portfolio theory formed by G. Markowitz as far back as 1952 remained almost the only quantitative method for solving the portfolio analysis problem [2]. Before proceeding to the Black-Litterman model, we briefly consider the Markowitz model and its shortcomings. Let there be $n$ types of assets from which the investor can form a portfolio. Capital is distributed between assets in shares $x_{i}, 0 \leq x_{i} \leq 1, \sum_{i=1}^{n} x_{i}=1$. Assets are characterized by efficiencies $R_{i}$, which are random variables with known mathematical expectations $M R_{i}=m_{i}$, and covariance matrix $\Sigma=\left\|\operatorname{cov}\left(R_{i}, R_{j}\right)\right\|$. The Markowitz problem is formulated as follows (1):

$$
\begin{aligned}
& \min _{x} x^{T} \sum x \\
& \sum_{i=1}^{n} x_{i}=1, \quad \sum_{i=1}^{n} m_{i} x_{i}=m_{p}, \quad x_{i} \geq 0, i \geq \overline{1, n}
\end{aligned}
$$

Although the Harry Markowitz model may seem attractive and wellgrounded from a theoretical point of view, a number of problems arise in its practical application [8, 11, 12]. Application of the Markowitz model in the Russian market also showed its inconsistency [2].

The main disadvantages of the Markowitz model are as follows: 
- The model does not take into account the market capitalization of assets.

- The model does not take into account the fundamental and other factors of profitability.

- The Markowitz model does not allow for taking into account the uncertainty levels for individual assets.

- The input parameters of the model are unstable in time.

- Portfolio dispersion as a risk measure characterizes the variability of portfolio returns both positively and negatively.

In the Black-Litterman model, most of these problems are solved by improving the theory [6] and the possibility of using expert estimates with confidence levels.

The Black-Litterman model was first published by Fisher Black and Robert Litterman from Goldman Sachs [4]. Investment bankers faced with the task of developing a practical model. Black and Litterman proposed the theory of "equilibrium approach" [6]. Moreover, equilibrium is understood as an idealized state in which demand is equivalent to supply. According to the authors, "natural forces", the functioning of which eliminates the deviation from equilibrium, function in the economic system. Equilibrium returns are calculated by the formula:

$$
\Pi=\lambda \Sigma w_{m k t}
$$

where $\Pi$ - equilibrium return vector; $\lambda$ - risk aversion coefficient; $\Sigma$ - covariance matrix of historical returns; $w_{m k t}$ - market capitalization vector of each asset relative to the capitalization amount of assets in the portfolio.

The coefficient $\lambda$ characterizes the investor's willingness to sacrifice the value of expected portfolio return in order to reduce its risk (3).

$$
\lambda=\frac{E(r)-r_{f}}{\sigma^{2}}
$$


where $E(r)$ - expected market

return, $r_{f}$ - risk-free interest rate, $\sigma^{2}=w_{m k t}^{T} \Sigma w_{m k t}$ - market portfolio

dispersion.

$$
\max _{w_{m k t}}\left(\left(w_{m k t}\right)^{T} \Pi-\frac{\lambda}{2}\left(w_{m k t}\right)^{T} \Sigma w_{m k t}\right) .
$$

Let

$U$ is a concave function and, therefore,

$U=\left(w_{m k t}\right)^{T} \Pi-\frac{\lambda}{2}\left(w_{m k t}\right)^{T} \Sigma w_{m k t}$. has a single global maximum.

$$
\frac{d U}{d w_{m k t}}=\Pi-\lambda \Sigma w_{m k t}=0 ; \Rightarrow \Pi=\lambda \Sigma w_{m k t}
$$

Thus, the equilibrium return The final formula is as follows: formula (2) is obtained.

$$
w=E[R](\lambda \Sigma)^{-1}
$$

Let us consider the Black- calculating the final portfolio (6). $K$ is the Litterman formula for the posterior number of subjective opinions, $N$ is the return vector (7). It is a key point before number of assets.

$$
E[R]=\left[(\tau \Sigma)^{-1}+P^{\prime} \Omega^{-1} P\right]^{-1}\left[(\tau \Sigma)^{-1} \Pi+P^{\prime} \Omega^{-1} Q\right]
$$

where $E[R]$ - new (posterior) mixed return vector $(N \times 1) ; \tau$ - scaling factor; $\Sigma$ - return covariance matrix (
$N \times N) ; P$ - matrix, which identifies assets for which the investor has a subjective opinion $(K \times N) ; \quad \Omega$ - 
diagonal covariance matrix with confidence levels for each subjective opinion $(K \times K) ; \quad \Pi$ - equilibrium return vector $(N \times 1) ; \mathrm{Q}$ - vector of subjective views $(K \times 1)$.

The investors often have their own position about the future profitability of an asset in a portfolio and this opinion may differ from the equilibrium return. Let us consider an example:

hares of Sberbank OJSC will yield a return of $10 \%$ (confidence level $=25 \%)$.

General case:

$$
Q+\mathcal{E}=\left[\begin{array}{c}
Q_{1} \\
\vdots \\
Q_{k}
\end{array}\right]+\left[\begin{array}{c}
\varepsilon_{1} \\
\vdots \\
\varepsilon_{k}
\end{array}\right]
$$

Error vector elements $\mathcal{E}$, usually nonzero. Variations $\omega$ of the error vector elements $\varepsilon$ form a diagonal covariance matrix $\Omega$ and demonstrate the uncertainty measure of subjective hares of Surgutneftegas OJSC will be $2.5 \%$ more efficient than shares of Rosneft OJSC $($ confidence level $=50 \%)$.

View 1 is an example of an absolute view, View 2 - relative. Uncertainty of subjective views is reflected in the error vector $(\varepsilon)$, whose elements are normally distributed with an average of 0 and a matrix $\Omega$. Thus, the final values of subjective opinions have the form of $Q+\varepsilon$.

Example:

$$
Q+\varepsilon=\left[\begin{array}{l}
10 \\
2.5
\end{array}\right]+\left[\begin{array}{l}
\varepsilon_{1} \\
\varepsilon_{2}
\end{array}\right]
$$

views. (9). The matrix is diagonal, because subjective opinions are independent of each other according to the model assumptions.

$$
\Omega=\left[\begin{array}{ccc}
\omega_{1} & 0 & 0 \\
0 & \ddots & 0 \\
0 & 0 & \omega_{k}
\end{array}\right]
$$


There are several methods for determining matrix elements $\Omega[1,7,9]$. In this work, using specific examples, we consider the possibilities of incorporating various types of forecasts into the Black-Litterman model: expert assessments of analytical departments; forecasts for multifactor models; predictions on intelligent methods (learning neural networks); forecasts on heuristic methods, forecast of technical analysis models. Due to limitations on the competitive work volume, only an overview of these methods is given

$$
P=\left[\begin{array}{ccc}
p_{1,1} & \cdots & p_{1, n} \\
\vdots & \ddots & \vdots \\
p_{k, 1} & \cdots & p_{k, n}
\end{array}\right]
$$

The first line of matrix $P$ reflects View 1. View 1 includes only one asset. View 2 is reflected in the second line, respectively. In case of relative views, the sum of all elements of the line shall be 0 .

The Black-Litterman model uses real historical data; therefore, statistical errors inevitably arise when

\footnotetext{
${ }^{5}$ The general name of a group of numerical methods based on obtaining a large number of implementations of a stochastic (random)
}

instead of specific numerical examples. These methods were not considered in the original articles of the model authors.

The values of returns for subjective views, located in the column vector $Q$, are introduced into the model using the matrix $P$. The presence of the influence of each subjective opinion is reflected in the line vector of dimension $1 \times N$. Thus, we get the matrix $P$ of dimension $K \times N$ for $K$ views.

General case:

Example (continued):

$$
P=\left[\begin{array}{cccc}
1 & 0 & 0 & 0 \\
0 & 1 & -1 & 0
\end{array}\right]
$$

evaluating input information. The Monte Carlo method ${ }^{5}$ was applied to reduce errors. First, the optimal BlackLitterman portfolio is determined $\widehat{w}_{0}$. Then it is proposed to use the Monte Carlo method:

1. Simulation of $K$ values of expected return on assets under the multidimensional distribution function

process, which is formed in such a way that its probabilistic features coincide with similar problem values being solved. 
$N(0, \tau \widehat{\Sigma}), \tau<<1$, and obtaining a new vector of averaged equilibrium returns

$$
\begin{aligned}
& \widehat{\Pi}_{i}=\widehat{\Pi}+\varepsilon_{i}, \quad \text { where } \\
& \varepsilon_{i} \sim N(0, \tau \widehat{\Sigma}), \tau<<1, i=1 \ldots K
\end{aligned}
$$

2. Recalculation of input parameters of the Black-Litterman model based on $\widehat{\Pi}_{i}$, obtained in the previous step, and $\hat{\Sigma}$.

3. Solving $K$ optimization problems in order to find a set of portfolios that are optimal in a sense $\widehat{w}_{i}$ , $i=1 \ldots K$. The higher $K$ is, the higher the accuracy is, but the computational load increases in turn.

4. Finding an unbiased estimate of averaged portfolio: $\widehat{w}=\frac{1}{K+1} \sum_{i=1}^{K} \widehat{w}_{i}$

Forecasts of analytical agencies can be used as expert estimates in the Black-Litterman model. As part of the work, we made a study of their predictive ability. For this purpose, we tested the hypothesis of statistical significance of the information coefficient IC. The study results are given below ${ }^{6}$ (Table 1 ).

\begin{tabular}{|c|c|c|c|c|}
\hline $\begin{array}{ll} & \mathbf{N} \\
\text { o. } & \end{array}$ & $\begin{array}{l}\text { Analytical } \\
\text { Department }\end{array}$ & $\begin{array}{l}\text { Mea } \\
\text { n(IC) }\end{array}$ & $\begin{array}{l}\text { STD } \\
\text { (IC) }\end{array}$ & $\begin{array}{l}\text { value }^{p-} \\
\text { test }\end{array}$ \\
\hline 1 & Citigroup Inc.* & 0.212 & $\begin{array}{r}0.57 \\
1\end{array}$ & $\begin{array}{r}0.0 \\
17\end{array}$ \\
\hline 2 & Deutsche Bank* & 0.182 & $\begin{array}{r}0.53 \\
9\end{array}$ & $\begin{array}{l}0.0 \\
43\end{array}$ \\
\hline 3 & Alfa Bank * & 0.181 & $\begin{array}{r}0.45 \\
3\end{array}$ & $\begin{array}{r}0.0 \\
14\end{array}$ \\
\hline
\end{tabular}

Table 1. Descriptive statistics and t-test results for IC

${ }^{6}$ An asterisk indicates analytical groups with adequate predictive ability. 


\begin{tabular}{|c|c|c|c|c|}
\hline 4 & Trojka Dialog & 0.127 & $\begin{array}{r}0.45 \\
2\end{array}$ & $\begin{array}{r}0.0 \\
85\end{array}$ \\
\hline 5 & Merrill Lynch & 0.147 & $\begin{array}{r}0.52 \\
9\end{array}$ & $\begin{array}{r}0.0 \\
71\end{array}$ \\
\hline 6 & UBS & 0.079 & $\begin{array}{r}0.40 \\
6\end{array}$ & $\begin{array}{r}0.2 \\
06\end{array}$ \\
\hline 7 & $\begin{array}{l}\text { BrokerKreditSer } \\
\text { vis }\end{array}$ & $\begin{array}{r}- \\
0.076\end{array}$ & $\begin{array}{r}0.49 \\
0\end{array}$ & $\begin{array}{r}0.7 \\
85\end{array}$ \\
\hline 8 & KIT Finans & $\begin{array}{r}- \\
0.039\end{array}$ & $\begin{array}{r}0.53 \\
2\end{array}$ & $\begin{array}{r}0.6 \\
75\end{array}$ \\
\hline
\end{tabular}

As already noted, each expert assessment is assigned a confidence level. There are two ways to assign confidence levels: quantitative and heuristic. Confidence levels can be assigned heuristically according to experience. An example is given below (Table 2Table 2). Here the values of confidence levels lie in the range from 0 to 1 .

Table 2. Percentage gaps reflecting confidence level in a view

\begin{tabular}{|c|l|}
\hline $\begin{array}{c}\text { Interval of percentage } \\
\text { ratio }\end{array}$ & $\begin{array}{c}\text { Semantics of the level of confidence } \\
\text { in the View }\end{array}$ \\
\hline $0-5 \%$ & Almost absolute confidence \\
\hline $5-15 \%$ & Strong confidence \\
\hline $15-30 \%$ & Normal level of confidence \\
\hline $30-50 \%$ & Average confidence \\
\hline $50-65 \%$ & Weak confidence \\
\hline $65-80 \%$ & Very weak confidence \\
\hline $80-100 \%$ & Almost complete lack of confidence \\
\hline
\end{tabular}

Let us consider the procedure for the quantitative formation of subjective views on the example of a factor model for the profitability 
dependence of Lukoil shares on two factors: BRENT oil price and national currency exchange rate (Table 3) [1]. The model can be considered lag, because the oil price is taken at the close of the American session, and the RUB/USD exchange rate in the form of yesterday's tomorrow rate. This model satisfies the Gauss-Markov conditions.

Table 3. Factor model parameters and test results

\begin{tabular}{|c|c|c|c|c|c|c|}
\hline \multirow[t]{2}{*}{$=17377^{N}$} & \multicolumn{6}{|c|}{$\begin{array}{l}\text { Regression Summary for Dependent Variable: } \mathrm{LKOH} \mathrm{R}= \\
, 8447289 \mathrm{R} ?=, 7133537 \\
\text { Adjusted } \mathrm{R} ?=, 7026886 \mathrm{~F}(2,1734)=70,637 \mathrm{p}<0,0000 \text { Std.Error } \\
\text { of estimate: }, 02799\end{array}$} \\
\hline & $\begin{array}{l}\text { B } \\
\text { eta }\end{array}$ & $\begin{array}{l}\mathrm{S} \\
\text { td.Err. }\end{array}$ & $\mathrm{B}$ & $\begin{array}{l}\mathrm{S} \\
\text { td.Err. }\end{array}$ & (1734) & $\begin{array}{l}\text { p } \\
\text {-level }\end{array}$ \\
\hline $\begin{array}{l}\text { I } \\
\text { ntercept }\end{array}$ & & & $\begin{array}{r}0 \\
.000781\end{array}$ & $\begin{array}{r}0 \\
.000672\end{array}$ & $\begin{array}{r}1 \\
.16189\end{array}$ & $\begin{array}{r}0 \\
.245438\end{array}$ \\
\hline RENT & $\begin{array}{r}0 \\
.237820\end{array}$ & $\begin{array}{r}0 \\
.023438\end{array}$ & $\begin{array}{r}1 \\
.291805\end{array}$ & $\begin{array}{r}0 \\
.028759\end{array}$ & $\begin{array}{r}1 \\
0.14668\end{array}$ & $\begin{array}{r}0 \\
.000000\end{array}$ \\
\hline $\begin{array}{r}\text { R } \\
\text { UB/USD }\end{array}$ & 0.102243 & $\begin{array}{r}0 \\
.023438\end{array}$ & 1.648184 & $\begin{array}{r}0 \\
.148590\end{array}$ & $\begin{array}{r}- \\
4.36222\end{array}$ & $\begin{array}{r}0 \\
.000014\end{array}$ \\
\hline
\end{tabular}

The expert assessment for the Black-Litterman model will be formed as follows: Shares of Lukoil OJSC will fall by $2 \%$ (according to the forecast of the factor model). The confidence level is $2.3 \%$ (according to the variation of residuals). The Black-Litterman formula elements will be assigned the following values:

$$
Q_{L K O H}=-0.021 \text {, }
$$

$\Omega_{L K O H}=0.023$. Since one can only get an absolute view using the factor model, the element of matrix $P$, corresponding to the view $K$ and the asset of Lukoil OAO will be equal to 1 .

In total, several experiments were conducted as part of this work: in the Russian (MICEX) and the American (NYSE) market, with a pronounced 


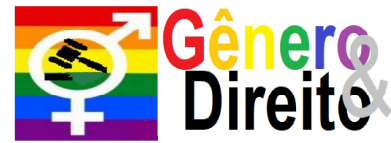

Periódico do Núcleo de Estudos e Pesquisas sobre Gênero e Direito Centro de Ciências Jurídicas - Universidade Federal da Paraíba V. 8 - N 06 - Ano 2019 - Special Edition ISSN | 2179-7137 | http://periodicos.ufpb.br/ojs2/index.php/ged/index growing trend and in the absence thereof.

The described submodels and forecasts of analysts with adequate predictive ability were used as expert estimates.
One of the experiments was conducted on the Russian market (MICEX) in the post-crisis period The results are presented below (Table 4).

Table 1. The experiment results on the Russian market (24.08.09 -

29.01.10).

\begin{tabular}{|c|c|c|c|c|c|c|}
\hline o & hare & $\begin{array}{r}\text { M } \\
\text { arket } \\
\text { portfolio }\end{array}$ & $\begin{array}{l}\text { Portfol } \\
\text { io by Black- } \\
\text { Letterman }\end{array}$ & $\begin{array}{r}\text { R } \\
\text { eturn on } \\
\text { assets }\end{array}$ & $\begin{array}{r}\text { Rate } \\
\text { of return on } \\
\text { market } \\
\text { portfolio }\end{array}$ & $\begin{array}{l}\text { Rate of } \\
\text { return on } \\
\text { Black- } \\
\text { Litterman } \\
\text { portfolio }\end{array}$ \\
\hline & ${ }^{\text {FLT }}{ }^{\text {A }}$ & $\begin{aligned} & 3 . \\
22 \% & \end{aligned}$ & $12.00 \%$ & $1.21 \%$ & $2.29 \%$ & $8.55 \%$ \\
\hline & ${ }_{\mathrm{AZP}}^{\mathrm{G}}$ & $\begin{array}{r}4 \\
6.56 \%\end{array}$ & $17.80 \%$ & $1.08 \%$ & $5.16 \%$ & $1.97 \%$ \\
\hline & $\begin{array}{l}\text { M } \\
\text { TSI }\end{array}$ & $\begin{aligned} & 4 . \\
89 \% & \end{aligned}$ & $22.62 \%$ & $0.77 \%$ & $1.50 \%$ & $6.96 \%$ \\
\hline & $\begin{array}{l}\mathrm{R}^{2} \\
\text { OSN }\end{array}$ & $5.56 \%$ & $17.35 \%$ & $4.71 \%$ & $3.76 \%$ & $2.55 \%$ \\
\hline & $\begin{array}{l}\text { S } \\
\text { BER }\end{array}$ & $9.35 \%$ & $26.47 \%$ & $0.96 \%$ & $\begin{array}{l}15.66 \\
\%\end{array}$ & $21.43 \%$ \\
\hline & RKA $^{\mathrm{U}}$ & $43 \%$ & $3.77 \%$ & $56 \%$ & $0.03 \%$ & $0.25 \%$ \\
\hline & & & & $\begin{array}{ll} & \mathrm{T} \\
\text { otal } & \end{array}$ & $\frac{28.41}{\%}$ & $41.71 \%$ \\
\hline
\end{tabular}

As can be seen from the table, the Black-Litterman portfolio return (41.71\%), taking into account expert assessments, is ahead of the market portfolio return $(28.41 \%)$. The market portfolio, in turn, is slightly ahead of the 
MICEX index (26.67\%) and the portfolio built according to the classical Markowitz theory (27.44\%). The BlackLitterman and Markowitz portfolios were compared at the same risk levels.

A completely similar experiment was conducted in a market where there is no pronounced growing
276

trend. The portfolio was formed from assets traded on the NYSE. In the absence of a pronounced trend, an optimal portfolio shows better returns than the market as a whole, represented by the NYSE. The results are presented below (Table 5).

Table 5. The experiment results on the American market (01.05.06 -

01.07.07).

\begin{tabular}{|c|c|c|c|c|c|c|}
\hline o. & hare $^{S}$ & $\begin{array}{r}\text { Mar } \\
\text { ket portfolio }\end{array}$ & $\begin{array}{l}\text { Portfol } \\
\text { io by Black- } \\
\text { Letterman }\end{array}$ & $\begin{array}{l}\text { Re } \\
\text { turn on } \\
\text { assets }\end{array}$ & $\begin{array}{r}\text { Rate } \\
\text { of return on } \\
\text { market } \\
\text { portfolio }\end{array}$ & $\begin{array}{l}\text { Rate } \\
\text { of return on } \\
\text { Black- } \\
\text { Litterman } \\
\text { portfolio }\end{array}$ \\
\hline & $\mathrm{C}$ & 17.13 & $10.00 \%$ & 8.0 & $1.37 \%$ & 0.80 \\
\hline & $\mathrm{P}$ & 38.94 & $15.80 \%$ & 10. & $4.21 \%$ & 1.71 \\
\hline & $\mathrm{A}$ & 7.79 & $24.62 \%$ & 23. & $1.79 \%$ & 5.66 \\
\hline & $\mathrm{I}$ & 7.48 & $20.35 \%$ & 12. & $0.91 \%$ & 2.48 \\
\hline & $\mathrm{J}$ & 8.41 & $23.47 \%$ & 12. & $1.04 \%$ & 2.91 \\
\hline & $E$ & 20.25 & $5.76 \%$ & 10. & $2.19 \%$ & 0.62 \\
\hline & & & & To & 11.51 & 14.18 \\
\hline
\end{tabular}

As in the previous example, let us compare the investment portfolio results compiled according to the BlackLitterman model with the classical Markowitz model results. Again, the portfolio compiled according to the classical Markowitz model differs little in profitability from the market portfolio and is even slightly inferior to it. At the same time, the portfolio according to the Black-Litterman model dominates again in terms of profitability (with approximately the same risk level of investment portfolios).

As part of the study of effectiveness of the Black-Litterman model, we carried out experiments for various values of the heuristic risk 
tolerance parameter $-\lambda$. Parameter values $\lambda$ were taken from 2 to 4 . We calculated performance evaluation coefficients for each portfolio (Sharpe, Schwager, Sortino, Treynor, and $\mathrm{M}^{2}$ coefficients). When forming portfolios, the same assets were used. The results grouped under $\lambda$, are presented below
(Table 6 and Figure 1). Here, risk is understood as the standard deviation of portfolio returns. The main conclusions that follow from this experiment are as follows: with increasing $\lambda$, the portfolio risk increases and the coefficients for assessing management effectiveness deteriorate.

Table 6. Experiment results with a growing trend with different parameter values $\lambda$

\begin{tabular}{|c|c|c|c|c|c|c|c|}
\hline $\mathbf{0}$ & eturn & isk & $\begin{array}{r}\text { Sh } \\
\text { arpe ratio } \\
\text { (RVAP) }\end{array}$ & $\begin{array}{c}\text { Sc } \\
\text { hwager } \\
\text { ratio } \\
\text { (AGRP) }\end{array}$ & $\begin{array}{r}\text { So } \\
\text { rtino ratio } \\
(\mathrm{Sr})\end{array}$ & 2 & $\begin{array}{r}\text { Tr } \\
\text { aynor ratio } \\
(\mathrm{RVOL})\end{array}$ \\
\hline & & & 4 & 5 & & & 8 \\
\hline & \multicolumn{7}{|c|}{$\lambda=2$} \\
\hline & \multicolumn{2}{|c|}{2} & 3.4 & \multirow[t]{2}{*}{0.3} & \multirow[t]{2}{*}{1.1} & & \multirow[t]{2}{*}{0.0} \\
\hline & $0 \%$ & .05 & 0 & & & .55 & \\
\hline & \multicolumn{2}{|c|}{2} & 2.7 & \multirow[t]{2}{*}{0.2} & \multirow[t]{2}{*}{1.1} & & \multirow[t]{2}{*}{0.0} \\
\hline & $2 \%$ & .07 & 1 & & & .45 & \\
\hline & \multicolumn{2}{|c|}{2} & 1.9 & \multirow[t]{2}{*}{0.1} & \multirow[t]{2}{*}{1.1} & & \multirow[t]{2}{*}{0.0} \\
\hline & $2 \%$ & .1 & 0 & & & .32 & \\
\hline & \multicolumn{2}{|c|}{2} & 1.8 & \multirow[t]{2}{*}{0.2} & \multirow[t]{2}{*}{1.1} & & \multirow[t]{2}{*}{0.0} \\
\hline & $5 \%$ & .12 & 3 & & & .31 & \\
\hline & \multicolumn{2}{|c|}{3} & 2.3 & \multirow[t]{2}{*}{\begin{tabular}{l|}
0.1 \\
\end{tabular}} & \multirow[t]{2}{*}{1.1} & & \multirow[t]{2}{*}{0.0} \\
\hline & $3 \%$ & .13 & 1 & & & .39 & \\
\hline & \multicolumn{7}{|c|}{$\lambda=3$} \\
\hline & \multicolumn{2}{|c|}{2} & 3.6 & \multirow{2}{*}{\begin{tabular}{|l|l|} 
& 0.4 \\
0 & \\
\end{tabular}} & \multirow[t]{2}{*}{1.1} & & \multirow{2}{*}{$2^{0.0}$} \\
\hline & $1 \%$ & .05 & 0 & & & .58 & \\
\hline
\end{tabular}


Periódico do Núcleo de Estudos e Pesquisas sobre Gênero e Direito

Centro de Ciências Jurídicas - Universidade Federal da Paraíba V. 8 - N 06 - Ano 2019 - Special Edition ISSN | 2179-7137 | http://periodicos.ufpb.br/ojs2/index.php/ged/index

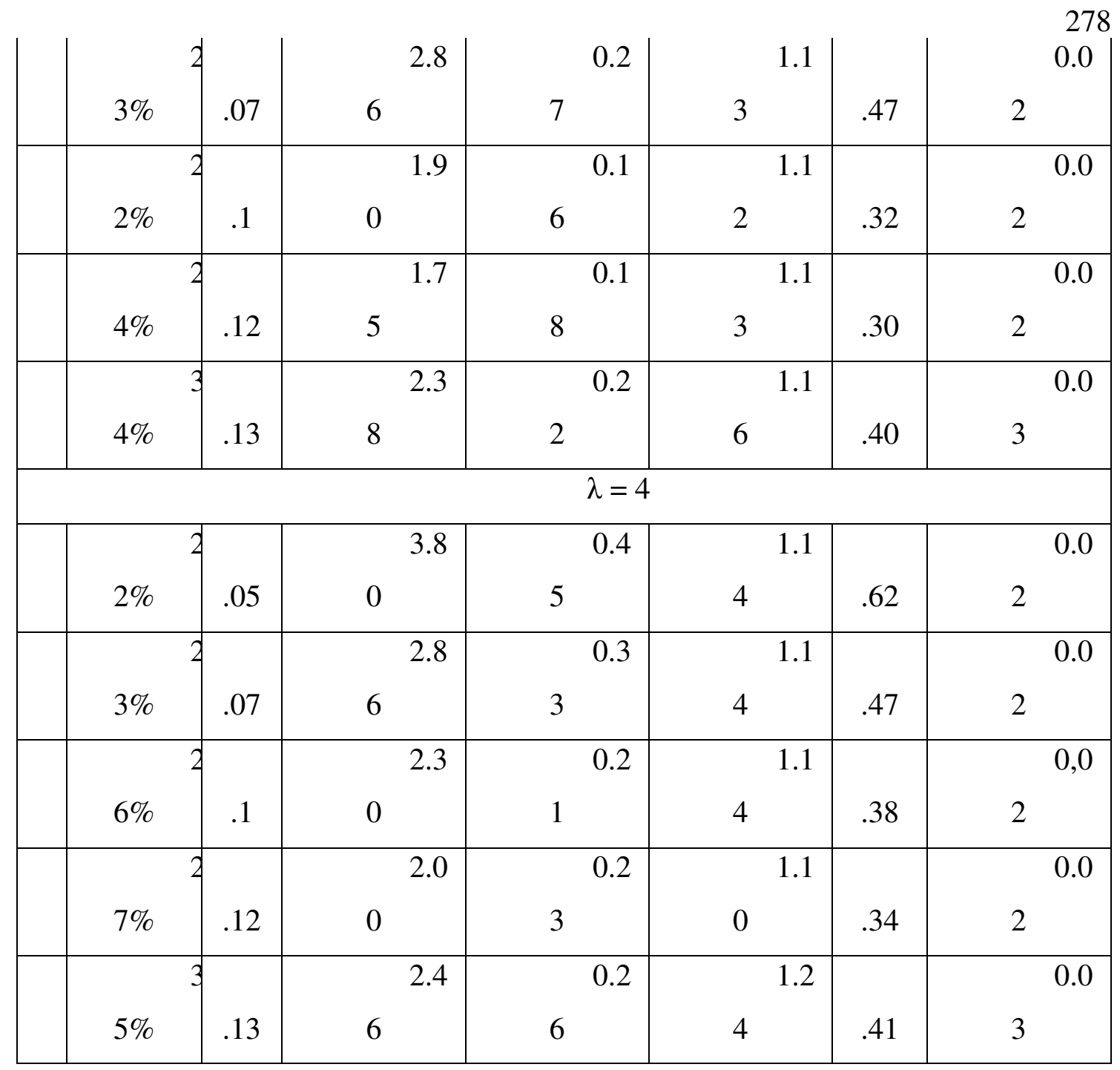

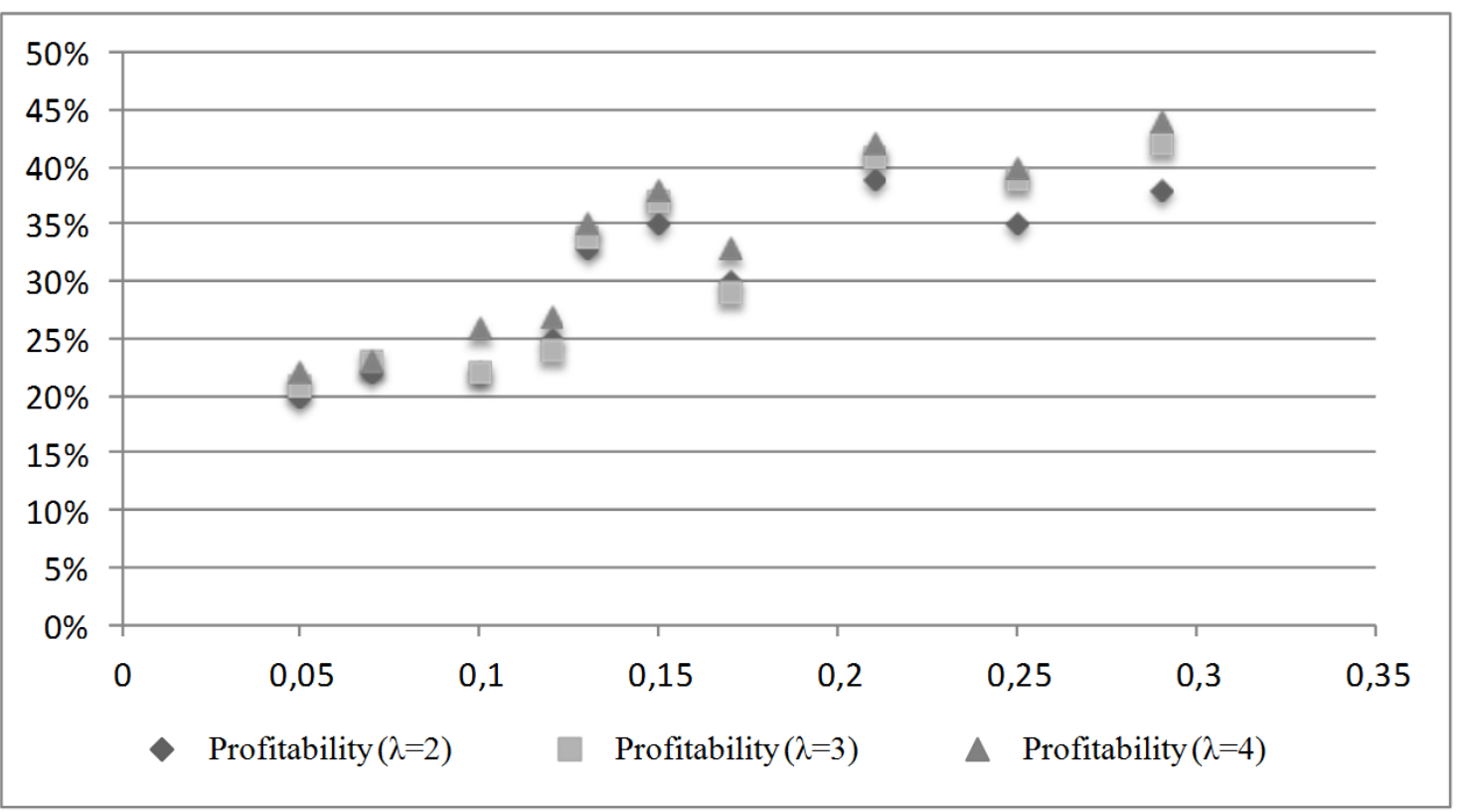




\section{Figure 1. Displaying the experiment results on the risk-return plane (with} a growing trend)

\section{Methods}

In the course of the study, the authors applied the following methods:

1. Selective analysis of specialized literature with a high citation index on the topics indicated in the article title. In particular, the modern portfolio theory of G. Markowitz, BlackLitterman model.

2. We carried out a comparative analysis of the collected information according to the criteria defined by the authors in order to identify the advantages and disadvantages of the considered methods and assess the possibility of their practical application.

3 . The study results were given the author's interpretation, and we made the respective conclusions.

\section{Results And Discussion}

As can be seen from the demonstration of results, a portfolio compiled according to Black-Litterman, taking into account expert evaluations of a complex nature, has a better rate of return compared to the market, an equilibrium portfolio and a portfolio compiled according to the classical theory (with approximately the same level of risk). A number of additional experiments conducted according to a similar scheme, but in other periods in the Russian and American markets, confirmed this fact. It should be noted that there was a decrease in the portfolio risk measure obtained using the Monte Carlo modeling procedure compared to the optimal portfolio.

\section{Summary}

Based on all the results obtained, it can be concluded that the Black-Litterman model is one of the necessary tools in modern financial management for the effective management of the securities investment portfolio. The model allows taking into account expert assessments of a complex nature: decisions of analytical departments, factor analysis, technical analysis, neural network models, HBP models, etc. The results of experiments with real investment portfolios in the 
Russian and American markets indicate the prospects of using the model in practical investment activities.

\section{Conclusions}

An investment portfolio compiled according to Black-Litterman, taking into account expert evaluations of a complex nature, has a better rate of return compared to the market, an equilibrium portfolio and a portfolio compiled according to Markowitz (with approximately the same level of risk). A number of additional experiments conducted according to a similar scheme, but in other periods in the Russian and American markets, confirmed this fact. The use of the Monte Carlo method makes it possible to level out statistical errors that may arise due to the partial use of historical information. The developed Black-Litterman solver software for building optimal and efficient portfolios allows solving the set optimization problems of finding an effective portfolio, taking into account the additionally given information, and conduct the Monte Carlo simulation process.

\section{Acknowledgements}

The work is performed according to the Russian Government Program of Competitive Growth of Kazan Federal University.

\section{Bibliography}

Galiev D.R. Using the Black-Litterman model and expert evaluations of a complex nature for the effective management of the securities portfolio. Software implementation and application results in the Russian and American markets // Final Scientific and Educational Conference of Students of the Kazan University in 2010: Collection of Articles / Kazan State University. Kazan, 2010. - P. 276-278.

Galiev D.R. Fundamental models of financial markets and factor pricing models. Verification of applicability for analysis of the Russian stock market. // Final Scientific and Educational Conference of Students of the Kazan University 2009: Collection of Articles / Kazan State University. - Kazan, 2009. P. 262-264.

Bevan A., Winkelmann K. Using the Black-Litterman Asset Allocation Model: Three Years of Practical 
Experience. // Fixed Income Research. 1998. - No. 6. - P. 7-18.

Black F.A. Global Portfolio Optimization / F.A. Black, R.D. Litterman // Financial Analysts Journal. - 1992. - No. 9. - P. 28- 43.

Haws J.C., Meyer C.D. Preconditioning KKT Systems // Numerical Linear Algebra with Applications Journal. 2001. - No. 11. - P. 168-173.

Litterman B.R. Modern Investment Management: An Equilibrium Approach. - Hoboken: «Wiley», 2007. $626 \mathrm{p}$.

Mankert C.N. The Black-Litterman Model. - Stockholm: «Royal Institute of Technology», 2007. - 111 p.

Michaud R. The Markowitz Optimization Enigma: Is «Optimized» Optimal? / R Michaud, O. Richard // Financial Analysts Journal. - 1989. No. 1. - P. 31-42.

Schutel A.S. The Black-Litterman Model For Active Portfolio Management
// Journal of portfolio management. 2009. - No. 11. - P. 18-32.

Walters J. The Black-Litterman Model in Detail / J.Walters // Harvard Management Company. - 2009. - No. 2. - P. $16-20$.

Galiev D.R., Isavnin A.G., Makhmutov I.I. (2017). Portfolio investment models with asymmetric risk measures and using genetic algorithms // Turkish Online Journal Of Design Art And Communication. Vol.7, Is.. - P.16521662.

Makhmutov I.I, Isavnin A.G, Karamyshev A.N,.Sych S.A. (2016). Classification approach in determination of knowledge in context of organization//Academy of Strategic Management Journal. Vol.15, Is.Special Issue. - P.40-46 